\title{
Effects of secondary fluid flow rate on cooling performance of vapor compression systems
}

\author{
Buhar sıkıştırmalı sistemlerin soğutma performansı üzerinde ikinci akışkanın kütlesel \\ debisinin etkileri
}

\author{
Faraz AFSHARí ${ }^{1, a}$, Doğan ÇíLOĞLU ${ }^{2, b}$, Mehmet Akif CEVIZZ, ${ }^{1, a}$, Murat CEYLAN*1,d \\ ${ }^{1}$ Erzurum Technical University, Faculty of Engineering and Architecture, Department of Mechanical Engineering, Erzurum \\ ${ }^{2}$ Ataturk University, Technical Vocational School of Higher Education, Erzurum
}

\begin{abstract}
The vapor compression cooling devices operate on the same principle as heat pumps. In these types of machines thermal energy is transferred from the cold environment to the warmer side using provided power by the compressor. In this study, the effect of air flow rate on the cooling performance of vapor compression cooling devices has been investigated by simulating a designed system in AVL CRUISETM M program. The simulated model is air-to-air cooling machine and refrigerant R134a was used as circulated gas inside the system. COP value of the system has been calculated in different working conditions and obtained results have been fully discussed. Accordingly, enthalpy variation in every element of the heat pump has been calculated in different working conditions and discussed on P-h diagram. This study presents a simulation method that is a practical solution method in the field of heat pumps, cooling machines and refrigerators which can be considered before installing device in order to have a proper prediction of the system performance.
\end{abstract}

Keywords: AVL CRUISETM M, Cooling performance, COP, Vapor compression system

\section{$\ddot{\boldsymbol{O}} \boldsymbol{z}$}

Buhar sıkışıtırmalı soğutma cihazları ısı pompalarıyla benzer prensipte çalışır. Bu tür makinelerde kompresör tarafindan tüketilen gücün kullanılmasıyla soğuk ortamdan sıcak olana ısl enerji transferi gerçekleştirilir. Bu çalışmada, AVL CRUISETM M programında tasarlanan bir sistemin simülasyonu yapılarak hava akı̧ hızının buhar sıkıştırmalı soğutma cihazının soğutma performansına etkisi incelenmiştir. Simülasyonu yapılan model havadan havaya soğutma makinesidir ve sistem içinde sirküle edilen gaz olarak soğutucu akışkan R134a kullanılmıştır. Sistemin COP değeri farkl çalışma koşullarında hesaplanmış ve elde edilen sonuçlar tümüyle tartışılmıştır. Bu doğrultuda, ısı pompasının her elemanındaki entalpi değişimi farkl çalışma koşullarında hesaplanmış ve P-h diyagramı üzerinde ele alınmıştır. Bu çalışma, sistem performansının doğru bir şekilde tahmin edilebilmesi için cihaz kurulumundan önce dikkate alınabilecek ısı pompaları, soğutma makineleri ve buzdolapları alanında pratik çözüm yöntemi olan bir simülasyon yöntemi sunmaktadır.

Anahtar kelimeler: AVL CRUISE ${ }^{\mathrm{TM}}$ M, Soğutma performansı, COP, Buhar sıklştırmalı sistem

\footnotetext{
${ }^{* d}$ Murat CEYLAN; murat.ceylan@erzurum.edu.tr; Tel: (0535) 83320 44; orcid.org/0000-0002-4958-0697

${ }^{a}$ orcid.org/0000-0001-9192-5604 $\quad{ }^{\mathrm{b}}$ orcid.org/0000-0002-7570-9271 $\quad{ }^{\mathrm{c}}$ orcid.org/0000-0001-6268-571X
} 


\section{Introduction \\ 1. Giriş}

The design, environmental pollution and its impacts on ozone layer depletion, global warming, climate change, and etc. as well as shortage of energy sources are primary significant issues that need to be investigated by researchers (Zheng et al., 2016). Heating, ventilation and air conditioning systems (HVAC) are a basic necessity in providing human thermal comfort. Energy consumed by HVAC systems accounts for almost half of total building energy consumption in developed countries and is expected to exceed $30 \%$ of global electricity demand by 2050 (Yang et al., 2019). Thus, HVAC systems have attracted great attention recently for their high efficiency, energy-saving, and environmental friendliness. Due to the continuous increase in energy demand, costs and related environmental problems, the energy-saving of these systems is a very important issue. The performance of a HVAC system depends on the adaptation of many energy equipment such as the tubing, compressor, and isolation components and the factors such as icing problem that cause the thermal resistance on the heat transfer surfaces. On the other hand, the fin spacing of the heat exchanger, air and refrigerant temperature, air relative humidity $(\mathrm{RH})$ and air velocity are parameters that affect the efficiency of the system. Many studies have been carried out to optimize HVAC system performance and thus increase the COP. Examples of these studies include electric heater defrosting (Bansal et al., 2010; Knabben et al., 2011) energy storage defrosting (Joppolo et al., 2012; Zhongbao Liu et al., 2017; Tan et al., 2015; D. Wang et al., 2012), and bypass cycle defrosting (Zhongbao Liu et al., 2018), hydrophobic fin coatings (Zhongliang Liu et al., 2006; F. Wang et al., 2015; S. W. Wang \& Liu, 2005), solid desiccant (Tang et al., 2016; Z. Wang et al., 2014) and so on. Schneider, (1978) proposed a new non-freezing air source heat pump water heater system coupled to an extra heat exchanger covered by a solid desiccant with an energy storage device. In their experiments, they found a $7.25 \%$ to $46.3 \%$ increase in the mean COP of the system compared to hot gas bypass defrost and electrical resistance heating, respectively. On the other hand, the effect of air velocity on possible icing on the evaporator is unclear. Schneider, (1978) reported that the frost growth was independent of the Reynolds number (Re) and thus the air velocity. ONeal and Tree, (1984) reported that at Reynolds numbers below the critical Reynolds number (about 15,900 for flow on a parallel-plate heat exchanger), the effect of air velocity on icing growth is significant, and otherwise, it is not significant. Lee et al., (2013) used a circular tube heat exchanger and found an increase in frost growth rate relative to air velocity, but not for air velocities greater than $0.97 \mathrm{~m} / \mathrm{s}$. In contrast to these researchers, Yan et al., (2003) reported higher frost growth at lower air velocities. Although a substantial amount of fundamental research has been done on frost under various operating conditions and geometries, the effect of air velocity on frost growth rate remains uncertain.

In this context, heat pumps and cooling devices have a notable role due to their importance in the effective heating and cooling in residential and industrial applications (Gaigalis et al., 2016). Moreover, heat pumps and cooling devices are employed in different industrial fields including food industry and drying (Ozyurt et al., 2004), air conditioning systems (Afshari et al., 2020; Yumrutaş \& Ünsal, 2012), drying of textiles (Ameen \& Bari, 2004) and etc. In general, vapor compression cycles can be compared in the terms of efficiency and performance using coefficient of performance or COP, which is a ratio of the useful cooling in refrigerators or heating in heat pumps to the work consumed by a compressor (Afshari et al., 2016).

In the literature heat pump systems have been evaluated in the terms of performance, energy and exergy efficiency considering overall system and its elements separately. The influence of the charge amount in vapor compression systems on the COP, power consumption and efficiency was investigated under different working conditions in order to achieve an optimal charge amount of the cooling refrigerant (Shen et al., 2009). Refrigerants replacing in a heat pump system can affect the performance deeply in terms of coefficient of performance. Karagoz et al., (2004) investigated refrigerant change and used the low ODP and low GWP gases in the same system. In addition, refrigerant mixtures were produced and various mass fractions and refrigerant types were examined. Piscaglia et al., (2016) conducted an experimental study to analyze seasonal performance of vertical borehole ground source heat pump device. The established experimental system was operated and its impact on the sedimentary heat reservoir was surveyed during four years.

Carrilho et al., (2017) studied the effects of icing on the external surface of the evaporators in refrigeration cycles. They discussed the ice layer formation over evaporator surface as heat exchanger for several values of air flow rate, 
temperature and relative humidity. Their evaluation on the icing thermal resistance demonstrated the importance of air conditions and heat exchanger configurations.

Nada et al., (2015) designed a test rig to study the fresh water production rate and cooling performance under different air flow rates, air inlet temperature, specific humidity and evaporator saturation temperature. According to their experimental results, an improvement on the fresh water production rate and the refrigeration capacity can be obtained with increasing air specific humidity and air mass flow rate.

Ramadan et al., (2015) concluded a study on the heat recovery concept in HVAC applications working on refrigeration cycles. They focused on the waste energy of the condenser hot air to preheat the domestic water. They have changed the water and air flow rates, and the results showed that the water can be heated depending on the mass flow rates and cooling loads of the HVAC system. According to their modeling results as the air flow rate decreases, the system efficiency increases.

This theoretical simulation study, devoted to a detailed attempt to evaluate the effects of flow rate of secondary fluid on the performance of vapor compression system. Energy based calculations have been performed to find out COP value of the heat pump under different working conditions. The literature research gap is the missing of P-h cycle motion of heat pump systems under different flow rates of secondary fluid, which is presented and discussed in this work. In addition, obtained results have been compared with the literature in terms of performance and COP value. There is a good agreement between research available in the literature with this present study.

\section{Simulation method}

\section{Simülasyon yöntemi}

The simulation method has been carried out using AVL CRUISETM $M$ program as a model-based system, which is a vehicle simulation platform. With the help of this program, high-quality, realtime capable subsystem models of the engine, powertrain, 1-dimensional fluid flow, aftertreatment, electrical and control system domains can be seamlessly integrated.

In the CRUISETM M program, it is also possible to perform modeling studies that support the simulation of refrigerant circuits such as air conditioning systems. In this study, the system model was created by using the basic cooling system elements in CRUISETM M. It should be stated that, CRUISETM is a flexible simulation solution that supports a wide range of applications and has a very high accuracy. By using a numeric solver and the ability to run real time applications, this simulation tool is very fast and accurate. In addition, this method can accurately and reliably predict the energy management of a designed energy system to evaluate operation efficiency and performance. In Figure 1, the schematic diagram of the simulation is presented including the components of the relevant system. This model shows a basic single-stage air conditioning circuit designed to include a sub-cooler. The circulating refrigerant is R134a.

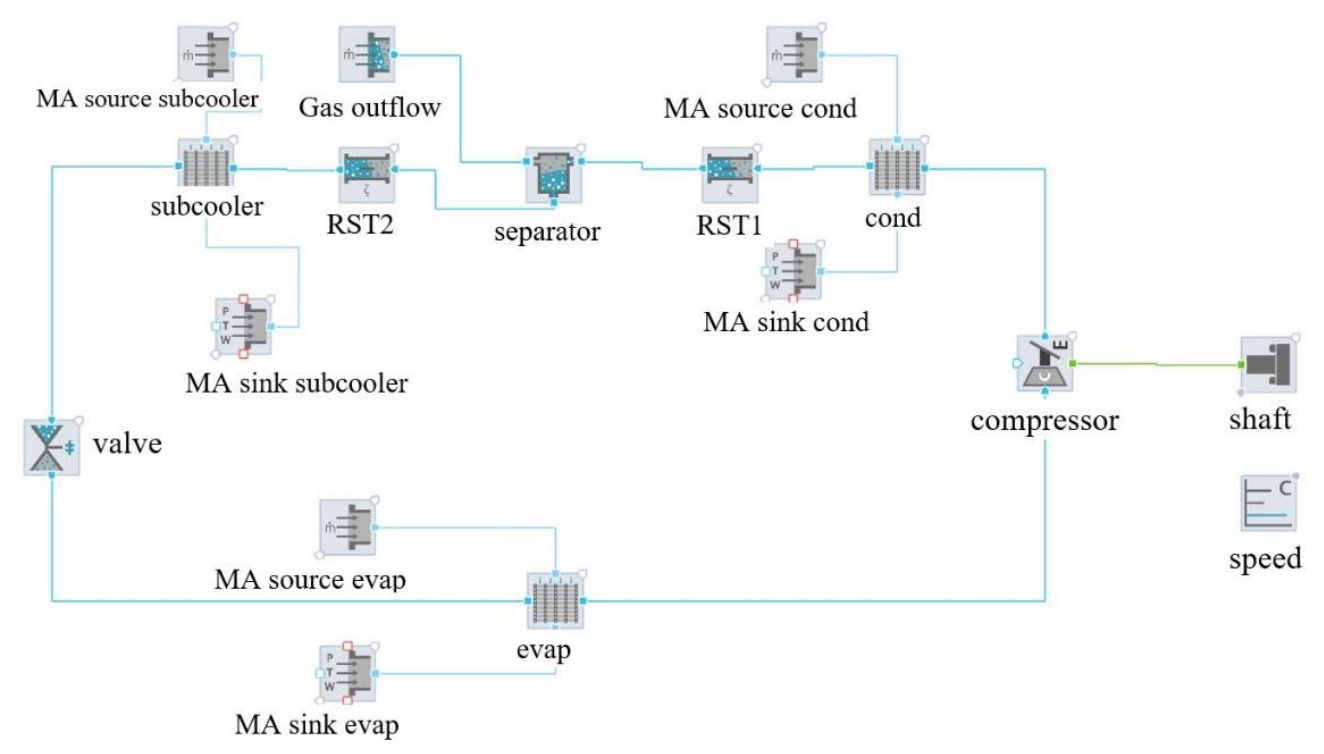

Figure 1. Schematic diagram of the basic single-stage air conditioning circuit Şekil 1. Temel tek kademeli iklimlendirme devresi şematik diyagramı 
In the model, there are four main components including evaporator, compressor, condenser and expansion valve. Evaporator is a multi-port extruded tubes heat exchanger used to simulate the heat transfer between moist air and refrigerant as well as the pressure-drop phenomena through the heat exchanger of a user-defined geometry. The heat exchanger is $60 \times 305.5 \times 199 \mathrm{~mm}$ in size and has 7 cells per path produced from aluminumbased material. Similarly, the heat exchanger model for the condenser is $17.5 \times 340 \times 530 \mathrm{~mm}$ in size and 5 cells per path. The compressor is a component used to simulate gas compression in the vapor compression cycle. Geometric volume and relative stroke are $1.5 \mathrm{e}-4 \mathrm{~m}^{3}$ and 0.616547 , respectively. The isentropic and volumetric efficiency of the compressor is 0.7 .

One of the factors that determines how much heat the cooler can absorb in the cooling circuits is subcooling. Sub-cooling is a process that takes place inside the condenser shortly before refrigerant passes through the evaporator. The main purpose of subcooling is to lower the temperature of the refrigerant to any temperature below its saturation temperature. In this regard, an extra heat exchanger which is $17.5-50-530 \mathrm{~mm}$ in size has been added between condenser and expansion valve in order to add the sub-cooling process. In the valve component of the program, mass flow rate is calculated in dependency of pressure drop using Bernoulli equation. The effective flow area of the valve is $4.08545 \mathrm{e}-7 \mathrm{~m}^{2}$. In the model, there is a separator component used to separate the coolant at the inlet port into a liquid and a gas phase. Additionally, there are two resistor components in the model simulating a pressure drop by the usage of a quadratic correlation. The pressure drops in the RST1 component between the condenser and the separator components and RST2 component between the separator and sub-cooler components have been defined as 0.025 bar. In this study, the system has been operated under different air flow rates including $0.1,0.15$ and $0.2 \mathrm{~kg} / \mathrm{s}$ to evaluate performance of the unite in different working conditions.

\subsection{Calculations}

\subsection{Hesaplamalar}

In this section, equations and formula used in the calculations are presented. In the air to air cooling systems, the heat transfer rate in the evaporator and condenser can be obtained from the air temperature change in the inlet and outlet sections as:

$$
\begin{aligned}
& \dot{Q}_{\text {evap }}=\left[\dot{m}_{a} c_{p, a}\left(T_{a, \text { in }}-T_{a, \text { out }}\right)\right]_{\text {evap }} \\
& \dot{Q}_{\text {cond }}=\left[\dot{m}_{a} c_{p, a}\left(T_{a, \text { in }}-T_{a, \text { out }}\right)\right]_{\text {cond }}
\end{aligned}
$$

On the other hand, enthalpy changes in the evaporator and condenser can be used to evaluate heat transfer rate as:

$$
\begin{aligned}
& \dot{\mathrm{Q}}_{\text {cond }}=\dot{m}_{r} \mathrm{~h}_{2}-\dot{m}_{r} \mathrm{~h}_{3} \\
& \dot{\mathrm{Q}}_{\text {evap }}=\dot{m}_{r} \mathrm{~h}_{1}-\dot{m}_{r} \mathrm{~h}_{4}
\end{aligned}
$$

Having the power consumption of the compressor and the heat transfer rate in the evaporator coefficient of performance (COPL) of the cooling device can be expressed as:

$$
\mathrm{COP}_{L}=\frac{\dot{\mathrm{Q}}_{\text {evap }}}{\dot{\mathrm{W}}_{\text {comp }}}
$$

\section{The simulation results and discussions \\ 3. Simülasyon sonuçları ve tartışma}

The defined cooling unite has been operated under different working conditions and obtained results have been presented on diagrams in order to evaluate efficiency of the system. As a first step, and with the aim of survey uncertainty of the simulation, heat transfer rate in condenser was calculated by using enthalpy variation of refrigerant and temperature change of the air as second fluid in different air flow rate in the condenser. In fact, heat transfer amount from the refrigerant should be equal to that of received by flowing air. In Fig. 2, obtained results show that a good agreement can be achieved by comparing results between two fluids.

The compressor can be defined as the main element of the system which is employed to provide the required energy to circulate refrigerant in the circuit. Pressure and temperature of the refrigerant are increased during compression process. In Fig. 3 , compressor inlet and outlet pressures have been presented with respect to the applied air flow rate. In the experiment's outlet pressure is approximately 6 times the inlet pressure. From the figure it can be seen that, with an increase in air flow rate pressure values increase in both inlet and outlet side due to receiving higher energy values in the evaporator. 


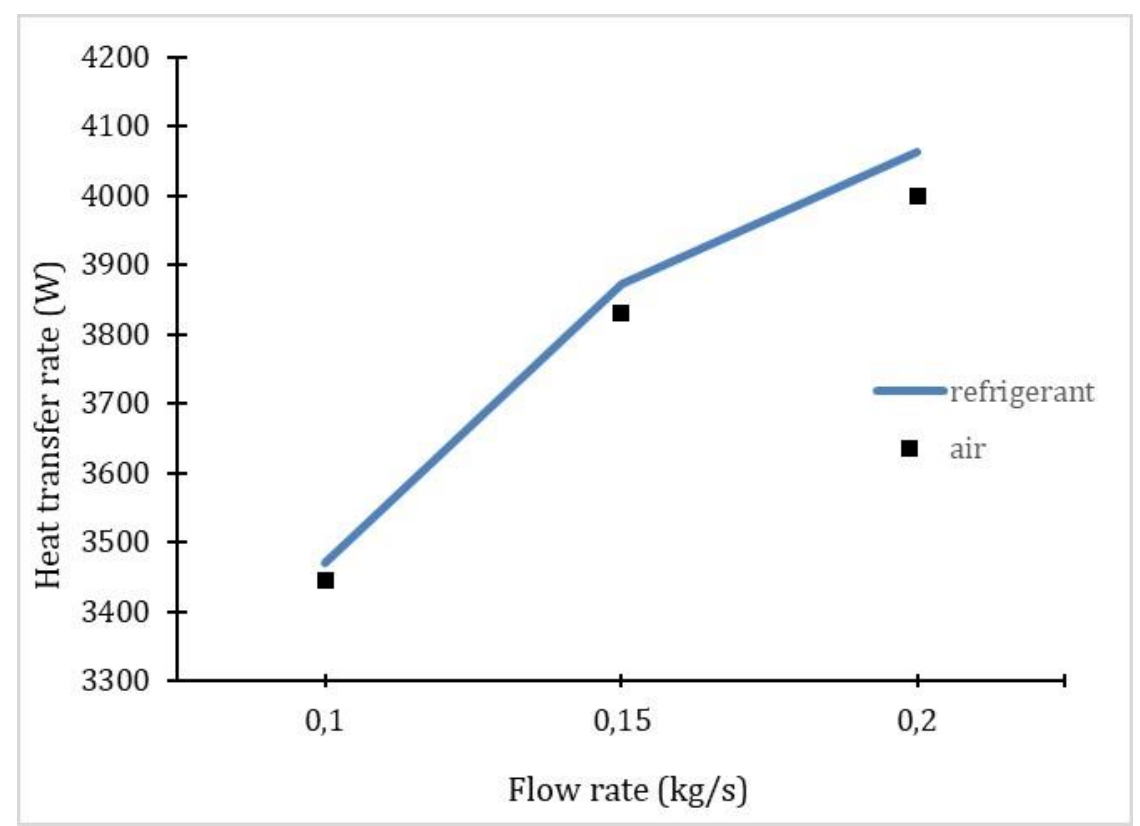

Figure 2. Heat transfer rate in condenser versus air flow rate Şekil 2. Havanın kütlesel debisine göre birim zamandaki ısı transferi

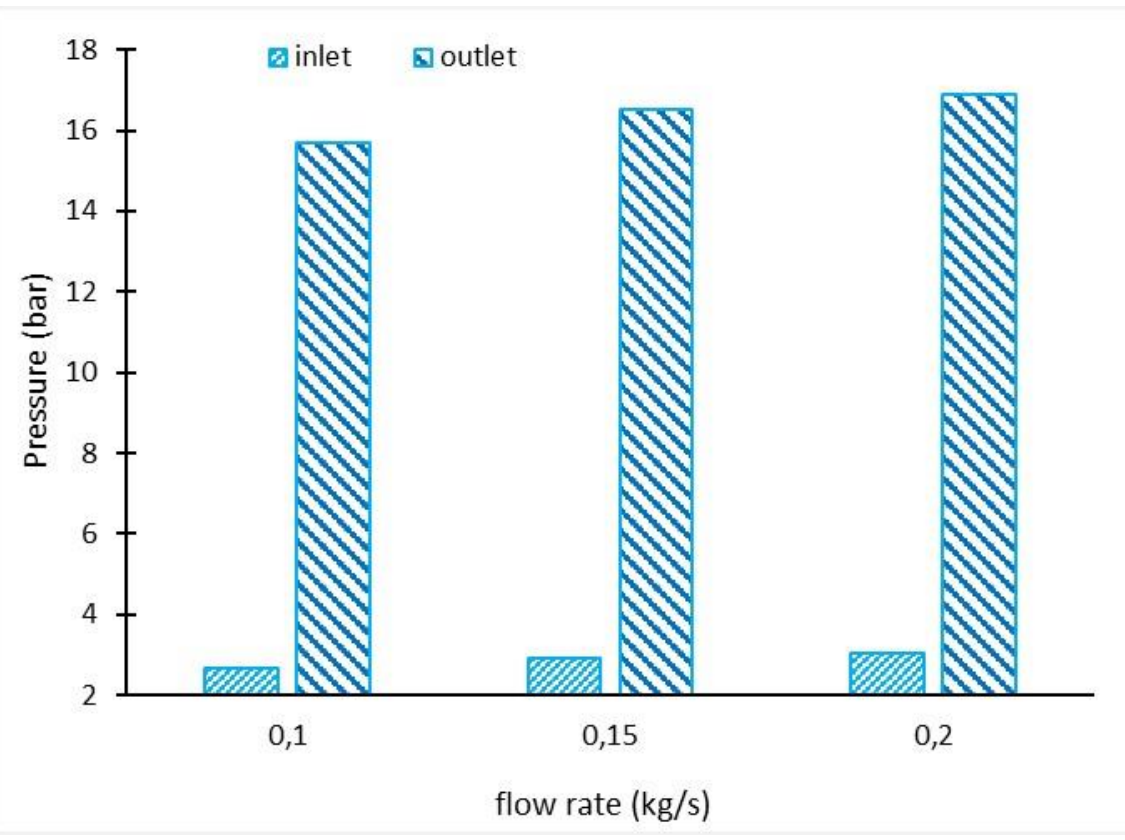

Figure 3. Compressor inlet and outlet pressures with respect to the air flow rate Şekil 3. Havanın kütlesel debisine göre kompresör giriş ve çıkış basınçları

In Fig. 4, compressor inlet and outlet temperatures have been presented with respect to the different air flow rate in the evaporator. Temperature rises significantly as a symbol of energy at the compressor outlet. At low air flow rates $(0.1 \mathrm{~kg} / \mathrm{s})$ the temperature drops even below zero. In general, with an increase in the air flow rate, the temperature of the compressor increases gradually as shown in the figure. 


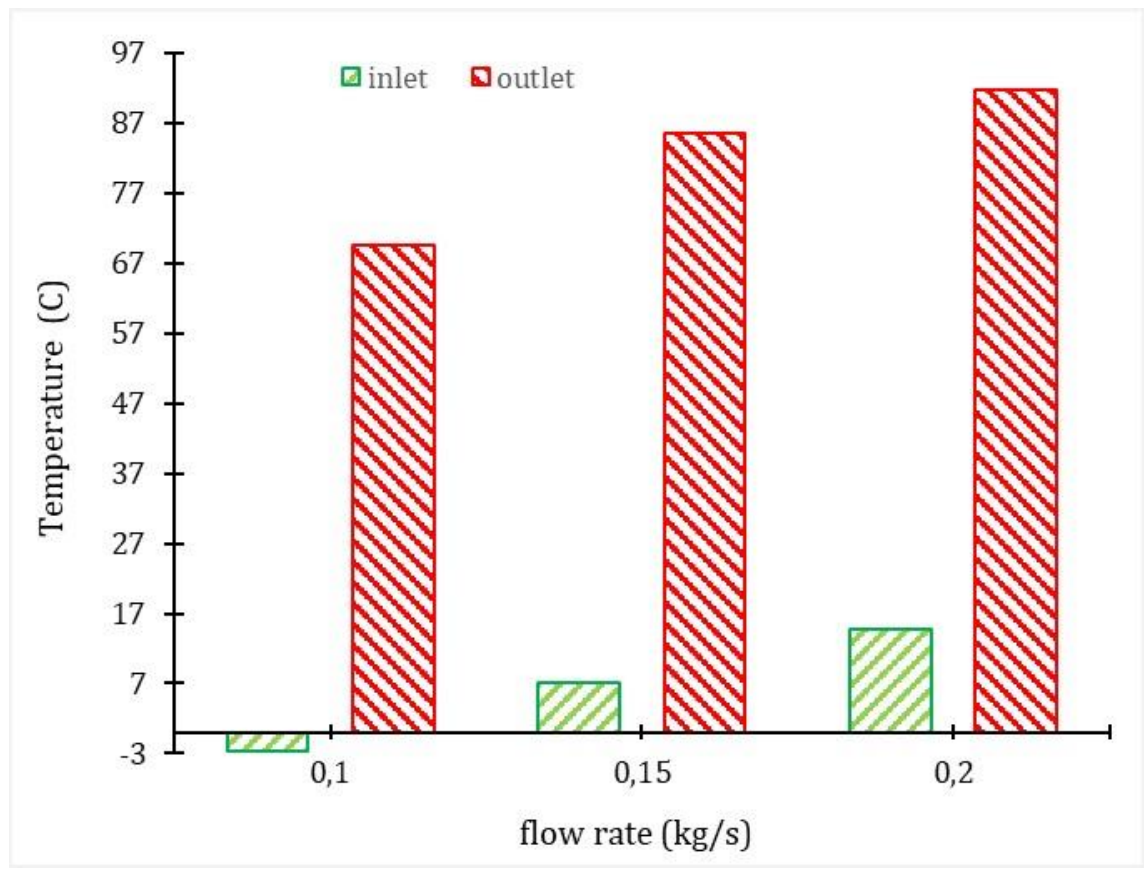

Figure 4. Compressor inlet and outlet temperatures with respect to the air flow rate Şekil 4. Havanın kütlesel debisine göre kompresör giriş ve çıklş sıcaklıkları

As one of the main factors in evaluating system performance, COP variations are presented in fig. 5. It can be stated that, COP value varies as a function of secondary fluid flow, which is air in this study. In the figure, it can be seen that the amount of COP increases significantly as the air flow increases. With increasing air flow from $0.1 \mathrm{~kg} / \mathrm{s}$ to $0.2 \mathrm{~kg} / \mathrm{s}$ the amount of COP increased by about $6 \%$.

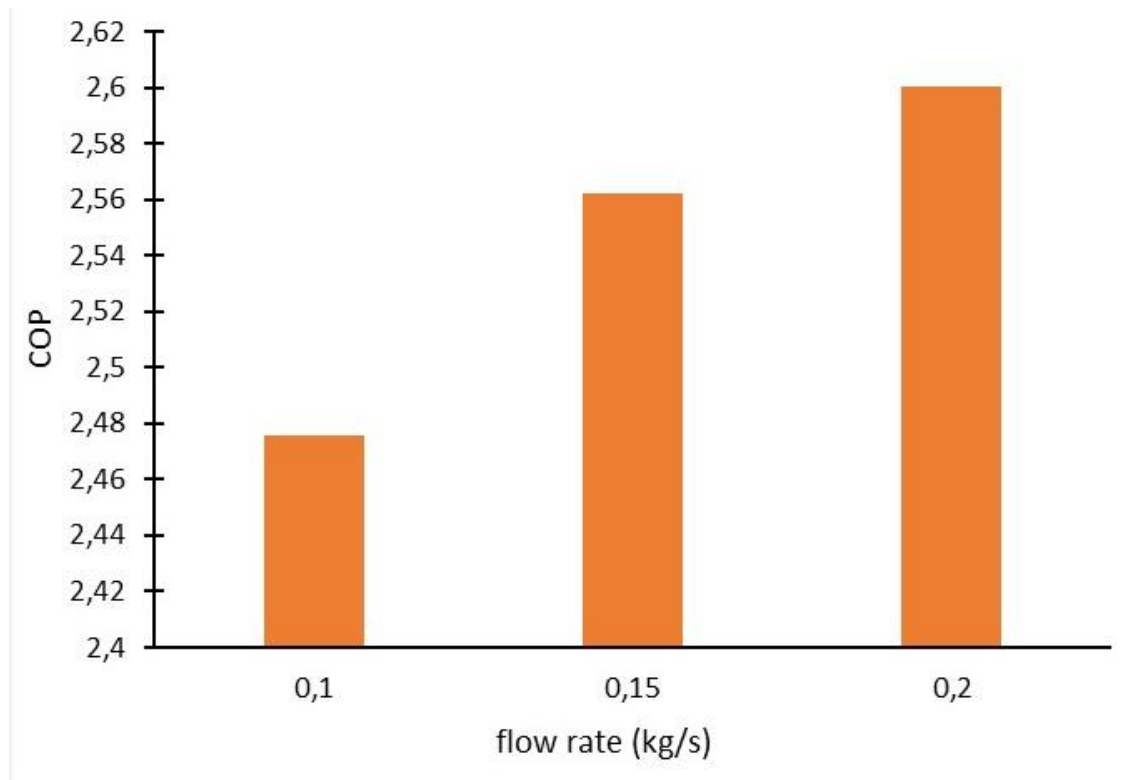

Figure 5. COP variations with respect to the air flow rate Şekil 5. Havanın kütlesel debisine göre COP değişimleri

In the vapor compression cycles, any change in the operating conditions can cause a change in the P-h diagram. A change in the energy provided in the evaporator or compressor can move the cycle up or down in the related P-h diagram. In Fig. 6, vapor compression cycles have been presented on $\mathrm{p}-\mathrm{h}$ diagram to show how any change in air flow rate changes the cycle. In the figure, cases one, two and three represented $0.1 \mathrm{~kg} / \mathrm{s}, 0.15 \mathrm{~kg} / \mathrm{s}$ and $0.2 \mathrm{~kg} / \mathrm{s}$ air flow rates respectively. From the figure it is clear that, as the amount of energy supplied to the evaporator increases by applying higher amount of air flow, the cycle is transferred to higher levels, where the amount of energy is also high. 


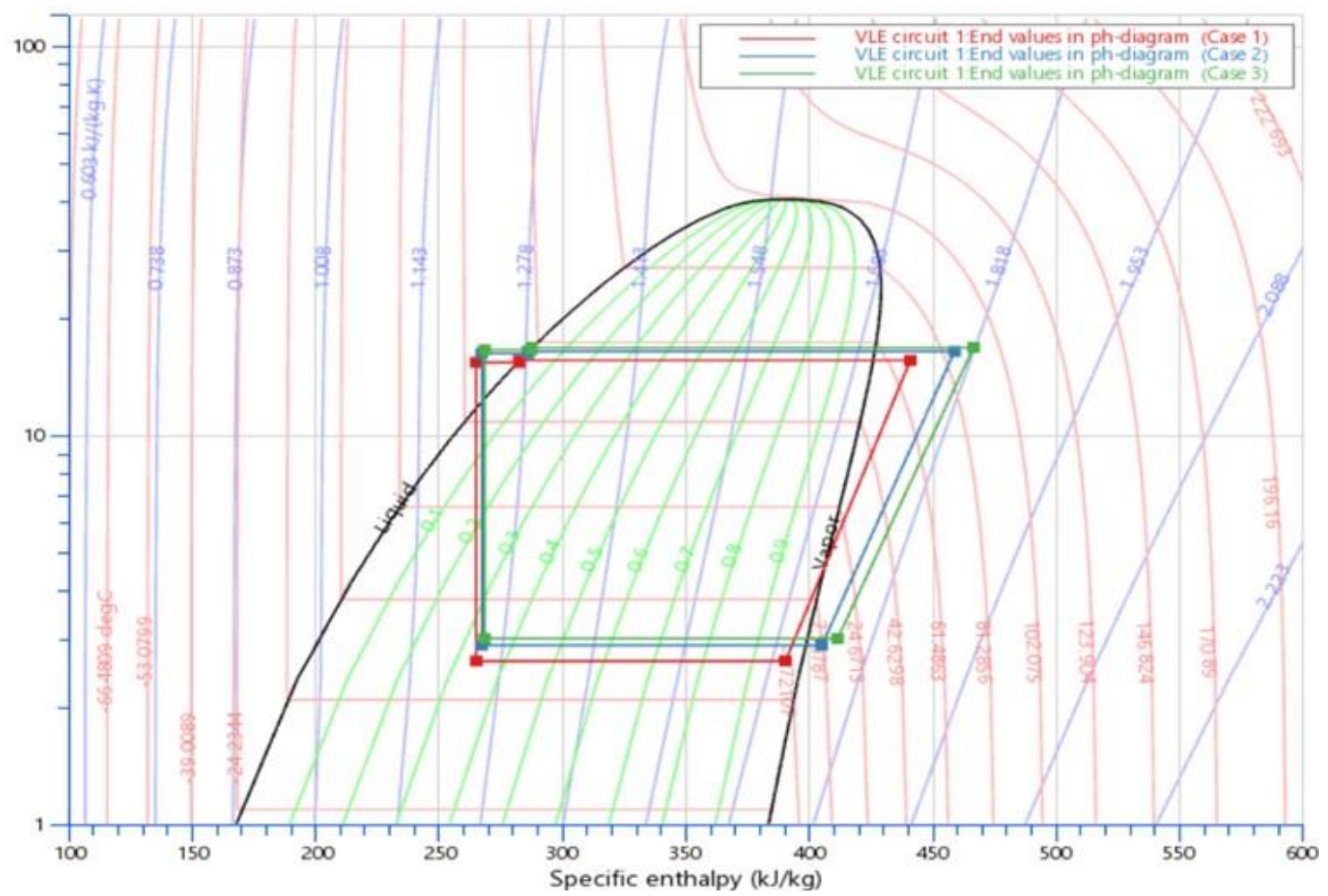

Figure 6. Vapor compression cycles for all experiments in the P-h diagram (case one $0.1 \mathrm{~kg} / \mathrm{s}$, case two $0,15 \mathrm{~kg} / \mathrm{s}$ and case three $0.2 \mathrm{~kg} / \mathrm{s}$ air flow rates)

Şekil 6. P-h diyagramında tüm deneyler için buhar sıklştırma çevrimleri (hava debileri birinci durumda $0.1 \mathrm{~kg} / \mathrm{s}$, ikinci durumda $0.15 \mathrm{~kg} / \mathrm{s}$ ve üçüncü durumda $0.2 \mathrm{~kg} / \mathrm{s}$ )

In Fig. 7, air temperature difference in evaporator versus air flow rate is presented. It can be stated that, as air velocity increases, the passing air has less time to cool down inside the evaporator and as a result the temperature change is not happening efficiently. Maximum change in the air temperature was recorded as $20.5^{\circ} \mathrm{C}$, when air flow rate is $0.1 \mathrm{~kg} / \mathrm{s}$. In Table 1 . a literature review has been carried out and the obtained results in the present study have been compared with the literature.

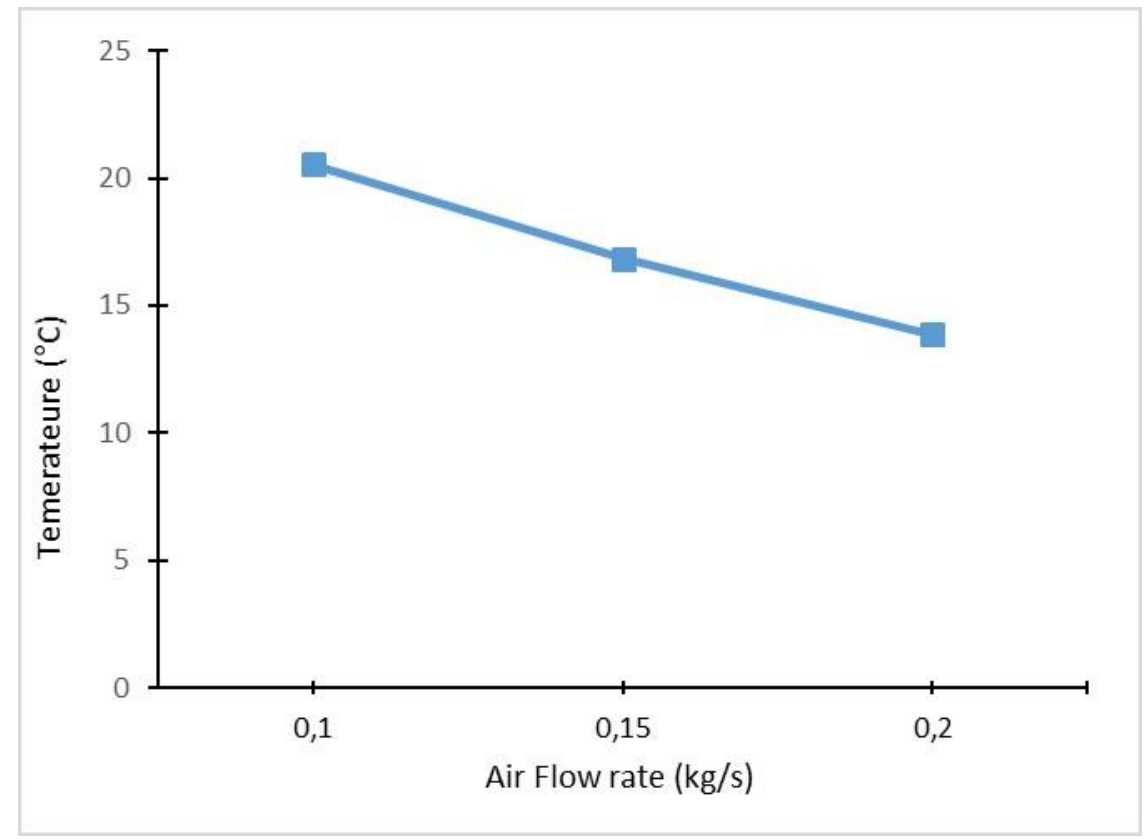

Figure 7. Air temperature difference in evaporator versus air flow rate Şekil 7. Havanın kütlesel debisine göre evaporatördeki hava sıcaklı̆̆ farkı 
Table 1. A comparison of the results obtained in the present study with the literature Tablo 1. Çalışmada elde edilen sonuçlar ile literatür sonuçlarının karşılaştırılması

\begin{tabular}{|c|c|c|c|c|c|c|}
\hline Reference & Refrigerant & Type of study & Type of analysis & COP & Location & Results \\
\hline Biaou et al., (2008) & - & $\begin{array}{l}\text { Simulation- } \\
\text { Theoretical }\end{array}$ & Energy & $3-6$ & Canada & $\begin{array}{l}\text { Various methods for supplying } \\
\text { domestic hot water were examined in } \\
\text { different climates and alternatives } \\
\text { such as a regular electric hot water } \\
\text { tank; ground source heat pump with } \\
\text { electric backup; thermal solar } \\
\text { collectors; a heat pump water heater } \\
\text { coupled to a space conditioning Heat } \\
\text { pump were compared in terms of } \\
\text { efficiency and performance. }\end{array}$ \\
\hline Bilgen et al., (2002) & $\mathrm{R} 410 \mathrm{~A}$ & $\begin{array}{c}\text { Experimental + } \\
\text { Simulation } \\
\text { (Theoretical) }\end{array}$ & Energy- Exergy & $3.8-7.4$ & Japan & $\begin{array}{l}\text { Simulation of a domestic heat pump } \\
\text { was performed by using experimental } \\
\text { data. It was observed that COP value } \\
\text { varies from } 3.8 \text { to } 7.40 \text {. The exergy } \\
\text { analysis was also performed and } \\
\text { exergy efficiency results were } \\
\text { between } 0.25 \text { to } 0.37 \text {. }\end{array}$ \\
\hline Al-Nadawi, (2021) & $\begin{array}{c}\text { R22, } \\
\text { R407C, } \\
\text { R404A and } \\
\text { R-134A }\end{array}$ & Experimental & Energy- Exergy & $\begin{array}{c}1.6 \\
(\operatorname{Max})\end{array}$ & Iraq & $\begin{array}{l}\text { A vapor compression chiller device } \\
\text { was operated by using different } \\
\text { refrigerants as working fluids. } \\
\text { Experiments were conducted at } \\
\text { various water and ambient } \\
\text { temperatures to specify the factors } \\
\text { which cause the energy deterioration. } \\
\text { It was observed that the total } \\
\text { irreversibility increases with } \\
\text { increasing water mass flow rate and } \\
\text { ambient temperature. }\end{array}$ \\
\hline $\begin{array}{l}\text { Afshari et al., } \\
(2019)\end{array}$ & $\mathrm{R} 407 \mathrm{C}$ & Experimental & Energy- Exergy & $\begin{array}{c}0.2 \\
\left(\mathrm{COP}_{\mathrm{L}}\right)\end{array}$ & Turkey & $\begin{array}{l}\text { A heat pump device was converted to } \\
\text { a cooling system and very low COP } \\
\text { was obtained. It was shown that, } \\
\text { evaporator working condition has a } \\
\text { notable impact on COP value and } \\
\text { refrigerator operate with a low } \\
\text { performance. }\end{array}$ \\
\hline Liu et al., (2013) & - & Experimental & Energy & $2.5-4.5$ & USA & $\begin{array}{l}\text { It was reported that, COP of the heat } \\
\text { pump is appropriate to use in the } \\
\text { space heating and hot water supply, } \\
\text { which can be proposed to provide } \\
\text { significant energy savings in hot } \\
\text { water supply and space heating. }\end{array}$ \\
\hline This study & $\mathrm{R} 134 \mathrm{a}$ & $\begin{array}{l}\text { Simulation- } \\
\text { Theoretical }\end{array}$ & Energy & $2.4-2.6$ & Turkey & $\begin{array}{l}\text { Simulation method was carried out to } \\
\text { analyze performance of a heat pump } \\
\text { in different working conditions. } \\
\text { Effect of flow rate of the secondary } \\
\text { fluid on COP value was studied. }\end{array}$ \\
\hline
\end{tabular}

\section{Conclusions \\ 4. Sonuçlar}

In this study, a simulation method was performed to evaluate the performance of an air-to air heat pump. In this regard, the simulated system was operated in different working conditions by changing the air flow rate in evaporator side. The finding of this study can be summarized as follows, Heat transfer in condenser was calculated, and then heat transfer rate variation with air flow was evaluated.

The difference between temperature and pressure at the inlet and outlet of the compressor was analyzed and the trend of changes in the mentioned parameters showed that pressure and temperature increase with increasing air flow.

Performance results revealed that, COP value of the heat pump increases about $6 \%$ when evaporator air flow rate increases from $0.1 \mathrm{~kg} / \mathrm{s}$ to $0.2 \mathrm{~kg} / \mathrm{s}$.

The working cycle in P-h diagram moves to upper side when air flow rate increases, accordingly it can be stated that, working pressure of the overall system increases with an increase in air flow rate. The relationship between air temperature and air flow velocity was analyzed and a downward trend in air temperature with the air velocity was observed. 


\author{
Nomenclature \\ Terminoloji \\ $\mathrm{C}_{\mathrm{p}, \mathrm{a}} \quad$ Specific heat capacity (J kg-1 K-1) \\ COP Coefficient of performance \\ h Enthalpy (kJ kg-1) \\ $\dot{\mathrm{m}} \quad$ Flow rate $(\mathrm{kg} \mathrm{s}-1)$ \\ $\mathrm{P} \quad$ Pressure $(\mathrm{kPa})$ \\ Refrig. Refrigerant \\ $\mathrm{T}$ Temperature $(\mathrm{C})$ \\ Q Heat transfer rate (W) \\ W Compressor power (W)
}

\section{Subscripts \\ Altsimgeler

$\begin{array}{ll}\text { a } & \text { Air } \\ \text { act } & \text { Actual } \\ \text { comp } & \text { Compressor } \\ \text { cond } & \text { Condenser } \\ \text { evap } & \text { Evaporator } \\ \text { r } & \text { Refrigerant } \\ \text { sys } & \text { System }\end{array}$

\section{Author contribution}

Yazar katkısı

Concept/Design: FA, DÇ, MAC, MC; Data Collection and/or Processing: FA, DÇ, MAC; Data analysis and interpretation: FA, DÇ, MAC; Literature Search: FA, DÇ, MAC, MC; Drafting manuscript: DÇ, MAC, MC; Critical revision of manuscript: FA, DÇ, MAC, MC

\section{Declaration of ethical code \\ Etik beyanı}

The authors declare that all of the rules stated to be followed within the scope of the "Higher Education Institutions Scientific Research and Publication Ethics Directive" were followed, and none of the actions specified under the title of "Actions Contrary to Scientific Research and Publication Ethics" have been taken.

\section{Conflicts of interest}

Çıkar çatışması beyanı

The authors declare that they have no conflict of interest.

\section{References}

Kaynaklar

Afshari, F., Comakli, O., Adiguzel, N., \& Karagoz, S. (2016). Optimal charge amount for different refrigerants in air-to-water heat pumps. Iranian Journal of Science and Technology, Transactions of Mechanical Engineering, 40(4), 325-335. https://doi.org/10.1007/s40997-0160028-2

Afshari, F., Karagoz, S., Comakli, O., \& Zavaragh, H. G. (2019). Thermodynamic analysis of a system converted from heat pump to refrigeration device. Heat and Mass Transfer, 55(2), 281-291. https://doi.org/10.1007/s00231-018-2412-5

Afshari, F., Sahin, B., Khanlari, A., \& Manay, E. (2020). Experimental optimization and investigation of compressor cooling fan in an air-to-water heat pump. Heat Transfer Research, 51(4). https://doi.org/

10.1615/HeatTransRes.2019030709

Al-Nadawi, A. K. (2021). Irreversibility analysis of R407C, R404A, and R134A as an alternatives of R22 in vapor compression chiller under cycling conditions. International Journal of Thermodynamics, 24(1), 24-29. http://doi.org/10.5541/ijot.797614

Ameen, A., \& Bari, S. (2004). Investigation into the effectiveness of heat pump assisted clothes dryer for humid tropics. Energy Conversion and Management, 45(9-10), 1397-1405. https://doi.org/10.1016/j.enconman.2003.09.001

Bansal, P., Fothergill, D., \& Fernandes, R. (2010). Thermal analysis of the defrost cycle in a domestic freezer. International Journal of Refrigeration, 33(3), 589-599. http://doi.org/10.1016/j.ijrefrig.2009.11.012

Biaou, A. L., \& Bernier, M. A. (2008). Achieving total domestic hot water production with renewable energy. Building and Environment, 43(4), 651660.

https://doi.org/10.1016/j.buildenv.2006.06.032

Bilgen, E., \& Takahashi, H. (2002). Exergy analysis and experimental study of heat pump systems. Exergy, an International Journal, 2(4), 259-265. https://doi.org/10.1016/S1164-0235(02)00083-3

Carrilho, D. G., Silva, P. D., Pires, L. C., Gaspar, P. D., \& Nunes, J. (2017). Quantification of the thermal resistance variation in evaporators surface due to ice formation. Energy Procedia, 142, 41514156. https://doi.org/10.1016/j.egypro.2017.12.339

Gaigalis, V., Skema, R., Marcinauskas, K., \& Korsakiene, I. (2016). A review on heat pumps implementation in Lithuania in compliance with the National Energy Strategy and EU policy. Renewable and Sustainable Energy Reviews, 53, 841-858.

https://doi.org/10.1016/j.rser.2015.09.029 
Joppolo, C. M., Molinaroli, L., De Antonellis, S., \& Merlo, U. (2012). Experimental analysis of frost formation with the presence of an electric field on fin and tube evaporator. International Journal of Refrigeration, 35(2), 468-474. https://doi.org/10.1016/j.ijrefrig.2011.10.017

Karagoz, S., Yilmaz, M., Comakli, O., \& Ozyurt, O. (2004). R134a and various mixtures of $\mathrm{R} 22 / \mathrm{R} 134 \mathrm{a}$ as an alternative to R22 in vapour compression heat pumps. Energy Conversion and Management, 45(2), 181-196. http://doi.org/10.1016/S0196-8904(03)00144-4

Knabben, F. T., Hermes, C. J. L., \& Melo, C. (2011). Insitu study of frosting and defrosting processes in tube-fin evaporators of household refrigerating appliances. International Journal of Refrigeration, 34(8), 2031-2041. http://doi.org/10.1016/j.ijrefrig.2011.07.006

Lee, S. H., Lee, M., Yoon, W. J., \& Kim, Y. (2013). Frost growth characteristics of spirally-coiled circular fin-tube heat exchangers under frosting conditions. International Journal of Heat and Mass Transfer, 64, 1-9. https://doi.org/10.1016/j.ijheatmasstransfer.201 3.04 .018

Liu, X., Ni, L., Lau, S. K., \& Li, H. (2013). Performance analysis of a multi-functional heat pump system in heating mode. Applied Thermal Engineering, 51(1-2), 698-710. https://doi.org/10.1016/j.applthermaleng.2012.0 8.043

Liu, Zhongbao, Li, A., Wang, Q., Chi, Y., \& Zhang, L. (2017). Experimental study on a new type of thermal storage defrosting system for frost-free household refrigerators. Applied Thermal Engineering, 118, 256-265. https://doi.org/10.1016/j.applthermaleng.2017.0 2.077

Liu, Zhongbao, Zhao, F., Zhang, L., Zhang, R., Yuan, M., \& Chi, Y. (2018). Performance of bypass cycle defrosting system using compressor casing thermal storage for air-cooled household refrigerators. Applied Thermal Engineering, 130, 1215-1223.

https://doi.org/10.1016/j.applthermaleng.2017.1 1.077

Liu, Zhongliang, Wang, H., Zhang, X., Meng, S., \& Ma, C. (2006). An experimental study on minimizing frost deposition on a cold surface under natural convection conditions by use of a novel antifrosting paint. Part I. Anti-frosting performance and comparison with the uncoated metallic surface. International Journal of Refrigeration, 29(2), 229-236.

https://doi.org/10.1016/j.ijrefrig.2005.05.018
Nada, S. A., Elattar, H. F., \& Fouda, A. (2015). Experimental study for hybrid humidificationdehumidification water desalination and air conditioning system. Desalination, 363, 112125. https://doi.org/10.1016/j.desal.2015.01.032

ONeal, D. L., \& Tree, D. R. (1984). Measurement of frost growth and density in a parallel plate geometry. Ashrae Transactions, 90(2), 278-290.

Ozyurt, O., Comakli, O., Yilmaz, M., \& Karslı, S. (2004). Heat pump use in milk pasteurization: an energy analysis. International Journal of Energy Research, 28(9), 833-846. https://doi.org/10.1002/er.999

Piscaglia, F., Blasi, A., Del Moro, S., Polonara, F., Arteconi, A., Zanarelli, L., \& Renzulli, A. (2016). Monitoring of a vertical borehole ground-coupled heat pump system: A case study from a marly-limestone heat reservoir (Urbino, Central Italy). Geothermics, 62, 61-69. https://doi.org/10.1016/j.geothermics.2016.02.0 08

Ramadan, M., El Rab, M. G., \& Khaled, M. (2015). Parametric analysis of air-water heat recovery concept applied to HVAC systems: Effect of mass flow rates. Case Studies in Thermal Engineering, 6, 61-68. https://doi.org/10.1016/j.csite.2015.06.001

Schneider, H. W. (1978). Equation of the growth rate of frost forming on cooled surfaces. International Journal of Heat and Mass Transfer, 21(8), 1019$1024 . \quad$ https://doi.org/10.1016/00179310(78)90098-4

Shen, B., Braun, J. E., \& Groll, E. A. (2009). Improved methodologies for simulating unitary air conditioners at off-design conditions. International Journal of Refrigeration, 32(7), 1837-1849.

https://doi.org/10.1016/j.ijrefrig.2009.06.009

Tan, H., Xu, G., Tao, T., Sun, X., \& Yao, W. (2015). Experimental investigation on the defrosting performance of a finned-tube evaporator using intermittent ultrasonic vibration. Applied Energy, 158 , $220-232$. https://doi.org/10.1016/j.apenergy.2015.08.072

Tang, J., Gong, G., Su, H., Wu, F., \& Herman, C. (2016). Performance evaluation of a novel method of frost prevention and retardation for air source heat pumps using the orthogonal experiment design method. Applied Energy, 169, 696-708. https://doi.org/10.1016/j.apenergy.2016.02.042

Wang, D., Tao, T., Xu, G., Luo, A., \& Kang, S. (2012). Experimental study on frosting suppression for a finned-tube evaporator using ultrasonic vibration. Experimental Thermal and Fluid Science, $\quad 36, \quad 1-11$. 
https://doi.org/10.1016/j.expthermflusci.2011.03 .002

Wang, F., Liang, C.-H., Yang, M.-T., \& Zhang, X.-S. (2015). Preliminary study of a novel defrosting method for air source heat pumps based on superhydrophobic fin. Applied Thermal Engineering, 90, 136-144. http://doi.org/10.1016/j.applthermaleng.2015.07 .003

Wang, S. W., \& Liu, Z. Y. (2005). A new method for preventing HP from frosting. Renewable Energy, 30(5), 753-761. https://doi.org/10.1016/j.renene.2003.07.001

Wang, Z., Zheng, Y., Wang, F., Wang, X., Lin, Z., Li, J., \& Huan, C. (2014). Experimental analysis on a novel frost-free air-source heat pump water heater system. Applied Thermal Engineering, 70(1), 808-816. http://doi.org/10.1016/j.applthermaleng.2014.05 .038

Yan, W.-M., Li, H.-Y., Wu, Y.-J., Lin, J.-Y., \& Chang, W.-R. (2003). Performance of finned tube heat exchangers operating under frosting conditions. International Journal of Heat and Mass Transfer, $46(5)$,

871-877. http://doi.org/10.1016/S0017-9310(02)00346-0

Yang, Y., Cui, G., \& Lan, C. Q. (2019). Developments in evaporative cooling and enhanced evaporative cooling-A review. Renewable and Sustainable Energy Reviews, 113, 109230. https://doi.org/10.1016/j.rser.2019.06.037

Yumrutaş, R., \& Ünsal, M. (2012). Energy analysis and modeling of a solar assisted house heating system with a heat pump and an underground energy storage tank. Solar Energy, 86(3), 983-993. http://doi.org/10.1016/j.solener.2012.01.008

Zheng, Z., Xu, Y., Dong, J., Zhang, L., \& Wang, L. (2016). Design and experimental testing of a ground source heat pump system based on energy-saving solar collector. Journal of Energy Engineering, 142(3), 4015022. http://doi.org/10.1061/(ASCE)EY.19437897.0000288 